\title{
ENVIRONMENTAL-INDUCED DISPLACEMENT: POTENTIAL PROTECTION UNDER INTERNATIONAL LAW
}

\author{
Irawati Handayani1; Anisa Fauziah² \\ 1,2Faculty of Law, Universitas Padjadjaran \\ Email: irawati@unpad.ac.id
}

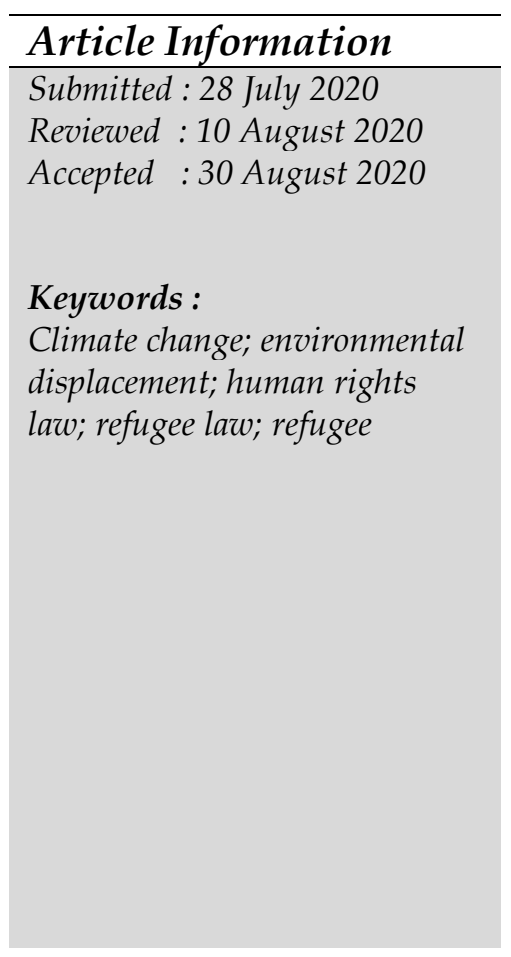

Abstract
Climate change, environmental degradation, and natural disasters
are some of the push factors of cross-border displacement. The
consequence of this movement is the loss oflegal protection from the
state of origin of the displaced persons. They are not categorized as
refugees as such; and no international law specifically regulates the
protection of climate displaced persons. This study used normative
approach by analyzing relevant international conventions and
other documents, as well as study results, assessments, and other
references related to displacement, human rights, and international
laws, in search of the legal protection of so-called "climate refugees"
based on international law. It elaborates the context of migration
caused by climate change and its relevance with the 1951
Convention on the Status of Refugee, possibility of interpretation
of the convention to cover environmental induced displacement and
protection under international human rights instruments. The
study concludes that it is rather difficult to include climate change-
induced displacement under the 1951 Convention on the Status of
Refugee despite any interpretations. However, it does not mean that
the displaced persons cannot be protected. International law,
especially International Human Rights Law extends protection to
people of such groups.

\section{Introduction}

Environmental migration has become a matter of debate and controversy among academicians and practitioners of international law. One of the sources of debate is the protection for people who leave their original territory across national borders and, at the same time, these people are not considered refugee under the 1951 Convention on Status of Refugee. In fact, environmental-displaced persons face threats related to their fundamental rights and protection from international law.

Displacement caused by environmental changes is nothing new. Changes in the environment greatly affect life of human beings, who are very dependent on surrounding environment. Rising sea levels and increasing frequency of extreme weather are some of the impacts of climate change that greatly affects humans. According to Keane (2004), climate change can be caused by two factors, including natural and anthropogenic disasters. What is more, climate change and global warming may result in loss of several islands following sea level rise (Epiney, 2011).

The most visible impact of climate change, either natural or anthropogenic disasters, is displacement of people who live around certain environments. These 
people are forced to leave their homes to save themselves because their surrounding environment is no longer suitable to sustain their lives. Natural disasters, throughout the history of human civilization, have always triggered population displacement (UNHCR, 1997). Migration in this case is one of the traditional ways of survival for populations facing climate change and disasters of environment (Smith, 2011).

In the 1990s, The UN Framework Convention for Climate Change declared climate change to be a matter of environmental degradation. Subsequently, discussions about climate change have developed since then. Migration has also been recognized as one of the consequences of climate change and global warming. Although the definition of refugees contained in international law does not cover people who are displaced due to climate change, the UNHCR as the agency dealing with refugees warns of the dangers that may arise due to the absence of a legal framework for "environmental refugees" (Faist, 2013). UNHCR further acknowledges that the consequences of climate change are very serious, including for refugees and others of concern. The UN General Assembly in December 2018, in the Global Compact on Refugees, later acknowledged that climate changes, environmental degradations, and natural disasters are the drivers of refugee movement (UNHCR, n.d.)

Literally, the definition of refugees in the Refugee Convention does not directly mention climate change and environment as factors causing refugee movement. However, many experts involve in various debates on the interpretation of the Refugee Convention. The focus mainly discusses whether persons who are displaced by climate and environmental changes can be classified as refugees and obtain refugee legal status. The definition certainly brings impacts on guaranteeing legal protection and human rights for these refugees. Given the importance of providing protection for people who are displaced for reasons uncovered by the 1951 Refugee Convention, this article discusses the relevance of the 1951 Refugee Convention for climate refugees and the possible interpretation of the 1951 Refugee Convention to protect the so-called environmental refugee.

\section{Research Methods}

The study used normative juridical methods with secondary data. For this purpose, the data consists of legal texts, related literature, and pre-existing research documents (Soekanto \& Mamudji, 2003). The material of related literature includes relevant international legal instruments and literature in the form of textbooks, journals, and other supporting materials like dictionaries, encyclopedias, and other materials that provide additional information.

\section{Research Result and Discussion}

\section{A. The Existence of Displaced Persons Caused by Climate Change}

Kolmannskog states that climate change affects a state's territory in several ways, such as loss of viable ecosystems, increasing soil salinity, flooding in coastal and lowland areas or loss of access to land due to weather changes such as major storms (Kolmannskog, 2008). Coastal states, especially those at low-lying ground, may lose their territory permanently to soil erosion caused by extreme weather and rising sea levels. Climate change has also driven millions of people to leave their homes. The 
displacement is predicted to increase in the future. Natural disasters such as more frequent storms, intense and prolonged droughts, rising sea levels, and other impacts of climate change exacerbate existing societal vulnerabilities and increase the likelihood of involuntary population displacement. Oxfam indicates that, between 2008 and 2016, people in low-and-middle-income states were five times more likely than people in high-income states to be displaced by sudden extreme weather disasters (Richards, Julie-Anne \& Bradshaw, 2017).

Several archipelagic states in the Indian and Pacific Oceans, such as Maldives, Kiribati, Tuvalu, Tonga, and Solomon Islands are affected also by climate change. In 2011, exactly $57 \%$ of the Solomon Islanders and $46 \%$ of the Tongan live outside their state's territory (Ferris, 2011) because most of their state's territory has been submerged due to rising sea levels. A research by John Campbell from the University of Waikato in New Zealand shows that about 400,000 to 990,000 people from states in the Asia-Pacific have migrated both within and outside their respective state up to 2009 due to climate change that made their territory unfit to live in. This number is predicted to increase in 2050 to 665,000 up to 1,725,000 people (Ferris, 2011).

Bangladesh is also a state that is vulnerable to the impacts of climate change. McAdam states that, scientifically, the impacts of climate change will exacerbate the dangers of natural disasters that Bangladesh has faced, including sudden events such as floods, hurricanes, storm surges, waterlogging, salinity disturbances, and riverbank erosion, as well as disasters that occur slowly such as coastal erosion due to rising of sea levels and loss of land (McAdam, 2012). Sea level rise from climate change is expected to worsen conditions in Bangladesh, causing 30 percent of Bangladesh's coastal landmass to disappear in 2008 (Pender, 2008).

A study conducted by Displacement Solutions in 2010 concludes that six million people have been displaced due to the impacts of climate hazards in Bangladesh (Solution, n.d.). In addition, the Chief Advisor of the Government of Bangladesh also estimates that sea level rise will reach one meter and will displace 25 to 30 million people of Bangladesh (Solution, n.d.). The 2014 Intergovernmental Panel on Climate Change (IPCC) report on climate change also explains that in the near future millions of people will be forced to leave their homes due to climate change ((IPCC), 2014). In the worst-case scenario, climate change may cause about 200 million refugees, 20 times more refugees than currently protected by the United Nations (Biermann, F \& Boas, 2010).

The majority of population movements due to climate and environmental changes may happen internally within a state's borders. However, it does not cover the fact that there have been movements of population across national borders, which can threaten regional or international security. For example, people who are forced to move across borders due to climate and environmental changes have received resistance from surrounding states, as the one happened in India. India has eventually formed a 2100-mile fence along its border with Bangladesh (Friedman, n.d.).

The impact of these population movements is significant. The population movement may reduce natural resources, cause overpopulated areas, and exacerbate socio-economic and political tensions. The absence of legal protection for people who migrate due to climate change has become one of the major humanitarian challenge. 


\section{B. Judicial Order on Status of Refugee caused by Climate Change}

Climate refugees who are forced to move to other states often do not get protection in their destination states. Therefore, the refugees often apply to acquire refugee status for the purpose of proper protection. In practice, the applications for protection are often filed in local courts. For example, there is the case of Ioane Teitiota v. Chief Executive of the Ministry of Business Innovation and Employment. A Kiribati resident named Ioane Teitiota and family applied for "Climate Change Refugees" status. They attended the High Court to the Court of Appeal of New Zealand (Ioane Teitiota v. Chief Executive of the Ministry of Business Innovation and Employment, 2015). Ioane Teitiota, a citizen of Kiribati, was born on a coral island just north of Tarawa. In 2007, Teitiota and family immigrated to New Zealand because the area where they lived was nearly submerged due to rising of sea levels. The transfer of Teitiota and family eventually caused them to register as refugees based on the 1951 Refugee Convention to the authorities of New Zealand. However, the request was later rejected based on several considerations (Ioane Teitiota v. Chief Executive of the Ministry of Business Innovation and Employment, 2015).

The judge decided to reject the application due to several considerations. One of them is because there was no persecution factor or threats to Teitiota and family. According to the court, the 1951 Refugee Convention requires an identifiable threat such as human factor. However, in Teitiota's request, the court rejected the request because the threat referred to the impact of climate changes. According to the court, such threat could not be detected and identified. The next legal consideration is the absence of well-founded fear in this case. The court states that there was no evidence of any future fear that if Teitiota and family returned to their home state, their lives would be at risk. This fear cannot be proven because of the absence of physical threats in this regard (Ioane Teitiota v. Chief Executive of the Ministry of Business Innovation and Employment, 2015).

In the legal consideration, the judge states that the reasons of threats must be based on race, religion, nationality, membership of a certain social group, and political opinion. None of them could not be proven in the court because the threat of climate change is a natural threat that has no deal with specific groups. Finally, the court argues that the factor "being outside of the state's territory" as stipulated in the 1951 Refugee Convention was not fulfilled. Despite the fact that Teitiota and family were outside their home state's territory at the time of the threat, the factor was not seen individually but collectively. The court sees that most of the climate migrants are those who move only within their home state. Therefore, the factor cannot be fulfilled. For this reason, based on the four considerations above, both the High Court and the Supreme Court of New Zealand rejected the Climate Change Refugee status (Ioane Teitiota v. Chief Executive of the Ministry of Business Innovation and Employment, 2015).

The example shows that the Judge makes decision based on the elements recognized in the 1951 Refugee Convention. The fact that the family were forced to move places cannot be categorized as refugees. The case is one of reasons for this study to be conducted: to see the possibility of climate refugees getting protection under the international law. 


\section{Protection of Environmentally Displaced Person \\ 1. Refugee Protection under the 1951 Convention Relating to the Status of Refugee}

Historically, the 1951 Refugee Convention was a document to address the postWorld War II European refugee crisis (Hathaway, James C \& Foster, 2014). This can be seen from the temporal and geographical boundaries stipulated in Article 1A (2) of the Convention. It regulates that protection for refugees only applies to those who have a strong fear of persecution based on their racial, religious, nationality, or membership of social or political group, which occurred in the Europe prior to January 1, 1951. These restrictions were later removed and the definition of a refugee was expanded by the 1967 Protocol relating to Refugee Status (Hathaway, James C \& Foster, 2014).

Classically, based on the 1951 Convention Relating to the Status of Refugee, refugees are defined as follows.

"... owing to well-founded fear of being persecuted for reasons of race, religion, nationality, membership of a particular social group or political opinion, is outside the country of his nationality and is unable or, owing to such fear, is unwilling to avail himself of the protection of that country; or who, not having a nationality and being outside the country of his former habitual residence as a result of such events, is unable or, owing to such fear, is unwilling to return to it" (Article 1A (2)).

The scope of this definition of refugees was indeed Europe-centric from the beginning (Islam \& Bhuiyan, 2013) because the initial formation of this convention was to provide protection for people who moved places due to conflicts in mainland Europe. Before 1951, states of Europe drafted international legal standards for the displaced people to obtain international protection.

Further, Musgrave (2005) explains that the history of the Refugee Convention can be traced back to the early twentieth century. Prior to the refugee convention, customary international law imposed an obligation on states to protect only their respective citizens. This obligation does not apply to protect citizens of other states living within the borders of their state. States have discretion to accept immigrants whom they think will contribute to the economy or society in a positive way and to evict refugees on the assumption that the right to do so is attached to state sovereignty.

During the war from 1919 to 1939, many violent conflicts and political problems in Europe and the Middle East led to the movement of large numbers of people (Musgrave, 2005). This phenomenon contradicted respective states' desire to control migration. Thus, it makes the international community being aware of the need to respond to the refugee problem. The League of Nations then formulated an international agreement aiming to provide protection for refugees. However, the agreement only covers refugees in certain situations. Therefore, it is ad hoc in nature (UNHCR, 2000). The League of Nations then forms the categories of refugee status. First, the person is outside of home state; and second, the person has no protection from the government of home state (Gill, Goodwin \& McAdam, 2007).

After the end of World War II, Europe experienced a large influx of refugees. The fall of Nazi power, following their defeat, led to the disintegration of states and left 
1.25 million people without homes and citizenships (Islam \& Bhuiyan, 2013). It caused the international community to started realizing that the refugee phenomenon is not a temporary phenomenon. Therefore, a legal instrument is needed to establish normative standards for determining refugee status. Thus, the 1951 Convention Relating the Status of Refugees was adopted later by the United Nations on July 28, 1951; and it started effective on April 21, 1954 (Hathaway, James C \& Foster, 2014).

Furthermore, Hathaway \& Foster (2014) state that the main characteristics of the definition of refugees in the Refugee Convention are its strategic conceptualization and Eurocentric focus. The strategic dimension of the definition stems from the efforts made by Western states to give priority to the issue of protection to persons whose displacement is motivated by pro-Western political values. The limitation of protection can be seen from the statement that protection is given only to people who have a fear of persecution because of their civil and political status. Hathaway also criticizes that the refugee convention adopted incomplete and politically sided human rights reasons. Apart from the wish of the West to form a refugee convention to serve strategic political purposes, the majority of states that drafted the Convention also sought to create a rights regime that was conducive to distributing the post-war refugee burden from the shoulders of Europe.

By looking at the classic refugee concept contained in the 1951 Refugee Convention along with its expanded scope in the 1967 New York Protocol, it is inevitable that there are many questions about the relevance of the current definition. Challenges to this scope arise in various regions of the world. For example, in 1998, the General Secretary of Germany's Liberal Party called for a waiver of the Refugee Convention because existing refugee boundaries have the potential to be abused and constitute a form of borderless migration. In the same year, the Austrian Presidency of the European Union (EU) suggested replacing the Refugee Convention with an EU asylum law that meets current requirements rather than geopolitically obsolete situation requirements. In April 2002, the UK Home Secretary, Jack Straw, criticized the Convention for being too broad for twenty-first century conditions and no longer being an adequate guide for policy in an era of mass aviation and economic migration. In addition, William Hague, the Conservative Party leader, states that the current asylum system is almost collapsing in an already very different world (Millbank, n.d.). With the emerging discourse regarding the scope of the definition of refugees, it is necessary to discuss the interpretation of refugee definition to answer the possibility of the inclusion of people who are displaced due to climate changes into the category of refugees as contained in the 1951 Refugee Convention.

\section{Definition of Climate Migrant}

Asmita Naik explains that the complexity of the migration problem has led to the emergence of various concepts and terminologies used to describe and to analyze various types of population movement or migration. In short, migration can be defined as the movement of a person or group of people to a new place of residence. The term that is often used to describe post-disaster population movement is forced migration. The International Organization for Migration defines forced migration as the non-voluntary movement of a person to avoid armed conflict, situations of violence, violations of their rights, and natural or manmade disasters. This term 
applies to the movement of refugees and the forced exchange of populations between states (Naik, 2009).

To date, there has not been a single definition or term that is universal to describe people who are forced to move across borders due to climate and environmental changes. Academicians use several terms, including environmental refugee, climate refugee, and climate migrant. In the absence of an internationally agreed definition, the IOM in 2007 developed a definition of "environmental migrants" as follows (Laczko \& Aghazarm, 2009a).

"Environmental migrants are persons or groups of persons who, for compelling reasons of sudden or progressive change in the environment that adversely affects their lives or living conditions, are obliged to leave their habitual homes, or choose to do so, either temporarily or permanently, and who move either within their country or abroad."

The IOM definition of environmental migrants seeks to cover population movements that are either temporary or permanent; internal or transboundary; voluntary or forced; and due to sudden or gradual changes in the environment. This means that in this case the term environmental migrants can be said to be a general and broad term that includes all forms of movement of people caused by climate change and the environment. In addition, The IOM and the Refugee Policy Center provide a broad definition of environmental refugees, namely people who have been displaced in their own state of residence or who have crossed international borders due to environmental degradation, damage, or destruction as the main cause of their displacement, although it does not have to be the only one. Similarly, Myers and Kent provide a broad definition of environmental refugees, namely "persons who no longer gain a secure livelihood in their traditional homelands because of what are primarily environmental factors of unusual scope" (Myers \& Kent, 1995).

Furthermore, the definition of environmental refugees is narrowed down. ElHinnawi (1985) defines it as follows.

"... those people who have been forced to leave their traditional habitat, temporarily or permanently, because of marked environmental disruption (natural and/or triggered by people) that jeopardized their existence and/or seriously affected the quality of their life."

The definition also refers to the term climate refugee. The use of the term refugee in this case refers to those who are forced to move due to the impulse of climate and environmental changes. Therefore, the rights to be protected as the rights of refugees are attached to them, despite the fact that the UNHCR does not currently recognize the term (Laczko \& Aghazarm, 2009b). The UNHCR in this case through the UN Secretary General Representative for Displaces Persons acknowledges displaced persons only in the context of movements within a state as follows.

"persons or groups of persons who have been forced or obliged to flee or to leave their homes or places of habitual residence, in particular as a result of or in order to avoid the effects of armed conflicts, situations of generalised conflicts, situations of generalised violence, violations of human rights or natural or man-made disasters, and who have not crossed an internationally recognised State border"(Guiding Principles on Internal Displacement, 1998). 
A clear definition is quite important since it can be used as a guide for policies of governments and international institutions to respond to various types of people movement caused by climate and environmental changes and to provide appropriate legal protection.

\section{Possible Interpretation of Refugee Term}

The definition of refugee enumerates in Article 1 (A) of the Refugee Convention. It includes several main elements. First, the person must be outside their home country. Second, they must be unwilling or unable to take advantage of their state's protection or return there. Third, such inability or reluctance must be linked to a legitimate fear of being persecuted; and the feared persecution must be based on reasons of race, religious nationality, membership of certain social groups, or political opinion (Keane, 2004). Literally, it can be said that the definition of refugees contained in Article 1A (2) of the Refugee Convention does not cover refugees caused by climate and environmental changes. In this regard, Keane states that it is possible to expand the definition of a refugee in the 1951 Refugee Convention along the lines and boundaries of human rights (Keane, 2004). Cooper (1996) states that the Refugee Convention recognizes refugee status that is caused by the denial of human rights. This can be seen from the five freedoms contained in the definition of refugees, which are stipulated in the Universal Declaration of Human Rights. In this case, the Refugee Convention should be able to recognize the right to seek safety as stated in Article 14 (1) of the Universal Declaration of Human Rights.

In the context of climate refugees, based on existing norms on refugee law, there is a minimal opportunity to receive international protection. However, Islam \& Bhuiyan (2013) mentions that the elements of the Refugee Convention are now beginning to be redefined and re-contextualized through the evolving international human rights legal regime. In addition, the word persecution is not defined explicitly under the refugee convention. This has opened the room for interpretation and expansion of the definition of refugees in the refugee convention (Islam \& Bhuiyan, 2013).

In interpreting the definition of a refugee, one must refer to Article 31 (1) of the Vienna Convention on the Law of Treaties. It states that the general rule of interpreting international treaties is to interpret them according to the ordinary meaning of words in the context of the treaty and to bear in mind their object and purpose. The object and objective of the Refugee Convention is to protect persons of concern (including asylum claimants, refugees, internally displaced persons, and stateless persons) from human rights violations in the form of persecution (Ponn, 2017). Apart from regulating who can be classified as a refugee protected under international law, refugee law is also closely related to human rights. Feller (2006) states "The refugee question (...) is in its essence a human rights question". The 1951 Refugee Convention is often recognized as part of human rights law (Hélène Ragheboom, 2017).

International conventions on human rights law also include the International Covenant on Civil and Political Rights (ICCPR) and the UN Convention Against Torture (CAT). International human rights legal instruments have long provided protection from refoulment, known as the non-refoulment principle (Ragheboom, 
2017). The principle of non-refoulment is referred to as the basis of international protection, which is considered part of customary international law (Lauterpacht \& Bethlehem, 2003). It is then codified in refugee convention and defined as obligations for states not to expel or return or rejecting a refugee, in any way, to the borders of a territory where the refugee's life or freedom can be threatened on the basis of race, religion, nationality, membership of a particular social group, or particular opinion (Ragheboom, 2017).

Currently, climate refugees have little opportunity to get protection. However, Ragheboom (2017) mentions that the principle of non-refoulement that is originated from international human rights law should theoretically fully cover climate refugees. With that in mind, this section attempts to explore other possible interpretations of the definition of refugees in the 1951 Refugee Convention to include climate refugees.

Cooper (1996) states that the 1951 Refugee Convention is a product of certain time and no longer fit its purpose. This may be a criticism of the 1951 Refugee Convention. However, looking at the history of refugee law, the adoption of this convention was intended originally to solve the European refugee crisis after the World War II. Thus, the limitation of the existing definition of refugee is a reflection of concerns in the past.

To include persons displaced by climate and environmental change within the scope of the Refugee Convention, without formal modification of the original provisions, a constructive interpretation of the text is required. This is in line with Usmawadi (n.d.) that developments in the international community have caused the existing provisions to be interpreted so that the international agreement can be applied.

Based on Article 31 (1) of the 1969 VCLT, an agreement is interpreted in good faith and in accordance with the usual meaning given to the terms of the agreement in the context and in terms of its aims and objectives. For the time being, the preamble of the 1951 Refugee Convention states that the Refugee Convention aims to guarantee the widest possible implementation of rights and freedoms for refugees based on the United Nations Charter and the Universal Declaration of Human Rights. It appears that there is a humanitarian objective of the 1951 Refugee Convention. Thus, it seems possible that the 1951 Refugee Convention could be interpreted in constructive ways to extend the protection it provides to other additional categories.

Article 1A (2) of the 1951 Refugee Convention clearly states that an alleged act of mistreatment will only be considered if it is related to one of the five reasons stated in the convention. Therefore, a person can be categorized as a refugee only when there is a causal relationship with one of the five reasons in the convention. William (2008) states that the provisions related to the reasons for persecution have been explicitly detailed in the convention, which only includes race, religion, nationality, and membership of certain social groups or political opinions. Then, it does not open space for interpretation to cover other reasons beyond those stipulated in the Convention. This means that to be recognized as a refugee under the 1951 Refugee Convention, a person fleeing an environmental disaster needs to attribute the threat of persecution to at least one of the five reasons.

Of the five reasons in the convention, the phrase for membership of a particular social group is the broadest category and is often considered ambiguous. Therefore, 
experts in various literatures have debated this phrase. Goodwin-Gill and McAdam (2017) state that travaux préparatoires do not clarify whether the notion of membership provisions in certain social groups in the convention was intended so that the Refugee Convention could be applied generally to unknown groups facing new forms of persecution or not. However, there is no reason why the phrase membership of a particular social group in the convention cannot be developed progressively (Goodwin-Gill \& Mc Adam, 2017). It can be seen as a space for interpretation of the provisions for membership of certain social groups in the Refugee Convention.

The interpretation of the phrase "membership of certain social groups", in order to include climate refugees has been voiced by several experts. Cooper (1996), for example, argues that environmental refugees are persecuted for reasons of their membership in a group of people who do not have the political power to protect their own environment. Under such conditions, their political powerlessness causes these people to become victims of environmental degradation. To support his view, Cooper (1996) cites the decision of the Federal Court of Australia in Denissenko v Hasket. Cooper strengthens it with the case of the Minister of Immigration \& Ethnic Affairs. The Australian Court rules that the phrase particular social group as the fourth reason in the convention can be interpreted as a group that can be recognized or understood in a society that is have the same interests or experiences. According to Cooper (1996), the group was formed independently of the persecution. For example, the lack of political power of Soviet citizens allowed the Soviet government to exploit recklessly nuclear power plants near populated but silent areas. It caused the local population to experience environmental degradation due to the Chernobyl disaster.

With this interpretation, climate refugees can claim based on the notion of persecution against certain social groups. States that will be faced with the most severe environmental damage from climate changes are dominated by developing states with little political power in the global arena and have no political influence to stop global warming threat. In this regard, Cooper (1996) argues that it is precisely because the citizens of the states most affected by global warming are members of social groups without the political power to protect their environment that governments of developed states continue to expose them to the risk of environmental degradation.

In this case, this study is in the position to argue that such interpretations are difficult to be accepted by the international community because, as stated by Kolmannskog (2008), persecution cannot be the basis for the formation of social groups. However, certain social groups must have inherent characteristics that cannot be changed that cause them to be persecuted for this, such as sexual orientation. On the other hand, Cooper (1996) proposes that environmental persecution is not aimed at groups with certain characters that cannot be changed. Developing states with little political power are not persecuted environmentally by developed states because of their characteristics. However, the condition makes them more vulnerable to the impacts of climate changes.

Foster (2007) put forward another interpretation with a predicament approach that the provisions for persecution as reason in the Refugee Convention should not be seen as a condition to identify them but should only focus on the fear of persecution. This approach includes threats of persecution that are not specifically targeted at specific groups, known as indiscriminate threats, into forms of abuse accepted in the 
Refugee Convention. For example, an armed conflict may affect children, elderly, or people with disabilities, even if they are not targeted deliberately. Foster's interpretive approach enables these people to become refugees (Ragheboom, 2017).

However, this study is in the position to view the approach too interpretive because it ignores several contexts in the agreement. From the perspective of textual approach, the refugee convention clearly states that there must be a causal relationship between persecution and the reasons are stipulated in the convention. This means that, in cases of persecution that are not targeted specifically at a particular group, it is difficult for victims to be protected as refugees under the Refugee Convention.

In addition, looking at current practice based on cases in several states such as New Zealand and Australia, states tend to refuse broad definition of refugees including climate refugees. Furthermore, the UNHCR also emphasizes that the organization does not introduce and approve the term climate refugee. Other organizations, such as IOM, also reject the term climate refugee. Seeing this, it is unlikely for the current international community to accept the interpretation of the definition to include climate refugees.

Since the difficulties in the interpretation of the Refugee Convention, other ways can be taken to include climate refugee under the 1951 Refugee Convention. It is by expanding the definition of refugee through the formation of new protocols. Historically, this has been done by the 1967 Protocol, which removed the temporal and geographic boundaries in the definition of refugees, or by establishing brand new convention.

\section{Protection of Environmentally Displaced Person under International Human Rights Law}

Considering the fact that it is quite difficult to include an environmentally displaced person in the category of refugee based on the 1951 Refugee Convention, this section describes possible protection that can be provided under the international law. Not being included in the category of the 1951 Refugee Convention does not mean that individual refugees are not entitled to protection from international law.

The 1951 Refugee Convention provides refugees with a number of rights and protections. One of the most important forms of protection is from being returned to the state of origin where they face the risk of persecution, according to Article 33 (1) of the Convention. This study views that despite the fact that climate refugees cannot get legal status of refugees, they still have the right to be protected like refugees, especially not to be returned to their home state where their lives are threatened. This is in line with Ragheboom, who states that the principle of non-refoulement should be applied to climate refugees because it is derived from international human rights law.

In addition, the principle of non-refoulement, stipulated in Article 33 of the 1951 Refugee Convention, has also developed into a customary international law norm. This means that it binds all states, event they that are not parties to the 1951 Conventions and/or the 1967 Protocol. Under international and regional human rights law, states are also prohibited from returning a person at risk of serious other human rights violations, including climate refugees. In this regard, international 
human rights law also plays important role, especially when refugee law is unable to provide protection for climate refugees.

McAdam (2012) states that although international law defines refugees in certain ways, this does not mean that people outside this definition do not deserve protection. Incidentally, state also has a legal obligation to provide protection to people who are forced to move from their homes but do not meet the definition of refugee in the 1951 Refugee Convention. This is known as Complementary Protection, which is provided by state in accordance with the protection obligations arising from international legal instruments and customs (Gill \& McAdam, 2007).

Complementary protection is defined as protection provided by states based on international protection needs. It is outside the framework of the 1951 Refugee Convention. The obligation of complementary protection can arise from international human rights law or other more general humanitarian principles, such as assisting people who are fleeing violence (McAdam, 2007). In the interim, Ragheboom (2017) states that complementary protection is a short term for the expansion of the scope of the non-refoulement principle, which is expanded based on international law. The main rights considered in the context of complementary protection are (1) the right to life; and (2) the right not to be subjected to torture or other cruel, inhuman, or degrading treatment or punishment. Although they are not the only rights that include non-refoulement obligations, the two rights are clearly recognized in international law giving rise to non-refoulement obligations and have been included in a number of domestic complementary protection regimes (Mc Adam, 2012). .

The right to life is protected based on Article 3 of the Universal Declaration of Human Rights, Article 6 of the International Covenant on Civil and Political Rights, and Article 6 of the Convention on The Rights of The Child. As explained by the UN Human Rights Committee, the right to life is the highest right that forms the basis of all human rights. This right is non-derogable and is recognized as source of nonrefoulement obligation.

The right not to suffer torture or cruel, inhuman, or degrading treatment or punishment is regulated in Article 7 of the ICCPR. Violation of these rights creates a non-refoulement obligation. Apart from being regulated in Article 7 of the ICCPR, it is also regulated in the CAT that prohibits forced return to situations where there are strong reasons to believe someone can face danger of torture.

Therefore, to find out whether non-refoulement obligations can apply to climate refugees, it is necessary to first analyze human rights violations that are experienced by climate refugees. Climate change affects the implementation of a person's human rights. Climatic processes (such as coastline erosion, coastal flooding, and rising sea levels, as well as more frequent and intense weather events such as hurricanes) affect agriculture, infrastructure, and habitability in certain regions of the world. Furthermore, such incidents could threaten socio-economic human rights such as the right to life, food, water, health, housing, and culture (McAdam, 2012).

The UN Human Rights Council later affirmed this in a resolution adopted in 2008 that climate change poses a direct and widespread threat to people and communities around the world and has implications for the full enjoyment of human rights (Resolution 7/23 on Human Rights and Climate Change - A/HRC/RES/7/23, n.d.). These rights include the rights to life, to adequate food, to the enjoyment of the 
highest standard of physical and mental health, to adequate housing, to selfdetermination, to drink safe water and sanitation, and to development (Resolution 32/33 on Human Rights and Climate Change - A/HRC/RES/32/33, n.d.). In addition, the Office of the High Commissioner for Human Rights also explains the impacts of climate change on human rights, as listed in the summary table below (Report of the Office of the United Nations High Commissioner for Human Rights on the Relationship between Climate Change and Human Rights - UN Doc.A/HRC/10/61, n.d).

Table 1. Effects of Climate Change on Human Rights

\begin{tabular}{ll}
\hline \multicolumn{1}{c}{ Climate Change Impacts } & \multicolumn{1}{c}{ Examples of Affected Rights } \\
\hline Extreme Weather Events & Right to Life \\
\hline $\begin{array}{l}\text { Increased food insecurity and risk } \\
\text { of hunger }\end{array}$ & $\begin{array}{l}\text { Right to adequate food, the right } \\
\text { to be free from hunger }\end{array}$ \\
\hline Increased water stress & Right to safe drinking water \\
\hline Stress on health status & $\begin{array}{l}\text { Right to the highest attainable } \\
\text { standard of health }\end{array}$ \\
\hline Sea level rise and flooding & Right to adequate housing \\
\hline
\end{tabular}

The wide variety of impacts of climate change and environmental disasters affect climate refugees' violated rights also vary. Only a handful of these rights are recognized currently as giving rise to protection obligations under the nonrefoulement principle.

The impacts of climate change and the environment indirectly threaten a person's right to life, especially the right to life is closely related to other human rights such as the right to an adequate standard of living, including food, clothing, housing, and improvement of living conditions, and the right not to be deprived of the means of living. The UN Human Rights Commission also agrees that the right to life includes existence in human dignity with minimum life necessities. Apart from that, the UN Human Rights Council in Resolution 7/23 on Human Rights and Climate Change also acknowledged that climate change has implications for the full enjoyment of human rights, including the right to life.

Indeed, the impacts of climate change and the environment are very diverse. In each case, the severity and level of damage can determine whether the right to life has been violated to give rise to non-refoulement obligations derived from human rights law based on complementary protection. It is usually up to states to assess whether climate refugees' right to life can be threatened if they are returned to their home state.

However, in general, it can be concluded that even though climate refugees cannot be protected under refugee conventions, recipient states still have the obligation to protect climate refugees according to the principle of non-refoulement based on complementary protection that is born from human rights law.

\section{Conclusion}

Climate refugees cannot receive protection under the 1951 Refugee Convention because they do not meet the requirements of the definition of refugee. In its 
development, several experts have tried to provide other interpretations of the definition of refugees in the 1951 Refugee Convention to include climate refugees. However, the attempts have failed to be accepted fully by the international community. Although climate refugees cannot get refugee legal status under the 1951 Refugee Convention, the forms of protection offered in the convention can be used as a reference standard for treating climate refugees. One of the most important is protection from refoulement.

Human rights law has expanded state protection obligations beyond the category of refugees. One of which is the obligation not to return a person to a place where his life is threatened, known as the non-refoulement principle. In the context of climate and environmental refugees, this means that states have an obligation under international human rights law (complementary protection) to protect climate refugees based on the non-refoulement principle.

Furthermore, in order to respond to the need for protection for climate refugees, the international community, through the United Nations, needs to broaden the definition of refugees in the 1951 Refugee Convention through the establishment of a new protocol or forming a new convention. This is intended to answer the problem of legal vacuum related to the protection of climate refugees. Specifically, it is quite strategic for states to integrate state obligations based on complementary protection resulted from international human rights law in the national laws of their respective states, specifically to address climate refugees.

\section{BIBLIOGRAPHY:}

\section{Books:}

Epiney, A. (2011). Environmental Refugees: Aspect of the Law of State Responsibility. In Migration and Climate Change. Cambridge University Press.

Ferris, E. (et. al. (2011). On the Front Line of Climate Change and Displacement: Learning from and With Pacific Island Countries. the Brooking Institutions.

Foster, M. (2007). International Refugee Law and Socio-Economic Rights. Cambridge University Press.

Gill, Goodwin \& McAdam, J. (2007). The Refugee in International Law. Oxford University Press.

Gill, Guy S Goodwin \& Mc Adam, J. (2017). UNHCR and Climate Change, Disaster and Displacement. UNHCR.

Hathaway, James C \& Foster, M. (2014). The Law of Refugee Status. Cambridge University Press.

Kolmannskog, V. O. (2008). Future Floods of the Refugees: A Comment on Climate Change, Conflict and Forced Migration. Norwegian Refugee Council.

Laczko, Frank \& Aghazarm, C. (eds. (2009a). Migration, Environment, And Climate Change: Assessing the Evidence. International Organization for Migration (IOM).

Laczko, Frank \& Aghazarm, C. (eds. (2009b). Migration, Environment, And Climate Change: Assessing the Evidence.

Lauterpacht, E. \& Bethlehem, D. (2003). The Scope and Content of the Principle of Non- Refoulement: Opinion. In Refugee Protection in International Law: unhcr's Global Consultations on International Protection (pp. 87-177). Cambridge University Press. 
Musgrave, T. (2005). Refugees. In Public International Law: An Australian Perspective (p. 301). Oxford University Press.

Mc Adam, J. (2007). Complementary Protection in International Refugee Law. Oxford University Press.

Mc Adam, J. (2012). Climate Change, Forced Migration and International Law. Oxford University Press.

Myers, Norman \& Kent, J. (1995). Environmental Exodus: An Emergent Crisis in the Global Arena". Project of The Climate Institute.

Naik, A. (2009). Migration and Natural Disaster. In C. Laczko, Frank \& Sghazarm (Ed.), Migration, Environment, And Climate Change: Assessing the Evidence (p. 252). IOM.

Ioane Teitiota v. Chief Executive of the Ministry of Business Innovation and Employment, (2015).

Report of the Office of the United Nations High Commissioner for Human Rights on the Relationship between Climate Change and Human Rights - UN Doc. A/HRC/10/61, paras 55.

Richards, Julie-Anne \& Bradshaw, S. (2017). Uprooted by Climate Change Responding To The Growing Risk of Displacement. Oxfam GB for Oxfam International.

Smith, J. R. (2011). Human Adaptation to Climate Change in the Archaeological Past. Radcliffe Institute for Advance Study's Science Symposium Something in the Air: Climate Change, Science and Poilicy.

Soekanto, Soerjono \& Mamudji, S. (2003). Penelitian Hukum Normatif.

Ragheboom, Helene. (2017). The International Legal Status and Protection of Environmentally Displaced Persons: A European Perspective. Brill Nijhoff.

UNHCR. (1997). The State of the World's Refugees: A Humanitarian Agenda.

UNHCR. (2000). The State of The World's Refugees 2000: Fifty Years of Humanitarian Action. Oxford University Press.

\section{Journals:}

Biermann, F \& Boas, I. (2010). Preparing for a Warmer World: Towards a Global Governance System to Protect Climate Refugees. Global Environmental Politics, 10(1), 60-88.

Cooper, J. B. (1996). Environmental Refugees: Meeting the Requirements of the Refugee Definition. New York University Environmental Law Journal, 6.

Faist, T. (2013). Disentangling Migration and Climate Change. Springer. https:/ / doi.org/10.1007/978-94-007-6208-4

Feller, E. (2006). Asylum, Migration and Refugee Protection: Realities, Myths and the Promise of Things to Come. International Journal of Refugee Law, 18, 509-536.

Islam, Rafiqul \& Bhuiyan, J. H. (eds. (2013). An Introduction to International Refugee Law. In Journal of Chemical Information and Modeling (Vol. 53, Issue 9). Martinus Nijhoff Publisher.

Keane, D. (2004). the Environmental Causes and Consequences of Migration: a Search for the Meaning of “Environmental Refugees." Geo. Int'l Envtl. L. Rev., 16(2), 209224.

Pender, J. (2008). Community-Led Adaptation in Bangladesh. Forced Migration Review, $31(54)$. 
Ponn, J. (2017). Addressing the Protection Gap of Environmental Refugees: A Reform of the 1951 Refugee Convention? Groningen Journal of International Law.

Ragheboom, Hélène. (2017). The International Legal Status and Protection of Environmentally Displaced Persons: A European Perspective. In Refugee Survey Quarterly (Vol. 4, Issue 1). Brill Nijhoff.

Usmawadi. (n.d.). Tinjauan Singkat Tentang Interpretasi Perjanjian Internasional Menurut Konvensi Wina Tahun 1969. Jurnal Hukum Dan Pembangunan, 18(3).

Williams, A. (2008). Turning the Tide: Recognizing Climate Change Refugees in International Law. Journal Law \& Policy, 30(4).

\section{Legal Documents:}

The 2014 Intergovernmental Panel on Climate Change (IPCC), (2014).

UNHCR. (n.d.). Climate Change and Disaster Displacement.

Resolution 32/33 on Human Rights and Climate Change - A/HRC/RES/32/33, Preamble Recital 10.

Resolution 7/23 on Human Rights and Climate Change - A/HRC/RES/7/23, Preamble Recital 1.

Guiding Principles on Internal Displacement, UN Doc. E/CN.4/1998/53/Add.2 (1998).

\section{Websites:}

Friedman, L. (n.d.). How Will Climate Refugees Impact National Security. https://www.scientificamerican.com/article/climate-refugees-nationalsecurity/

Millbank, A. (n.d.). The Problem with the 1951 Refugee Convention. 2000. Retrieved April 28, 2019,

https://www.aph.gov.au/about_parliament/parliamentary_departments/par liamentary_library/pubs/rp/rp0001/01rp05

Solution, D. (n.d.). Climate Displacement in Bangladesh. http:/ / displacementsolutions.org/wp-content/ uploads/DS-ClimateDisplacement-in-Bangladesh-Report-LOW-RES-FOR-WEB.pdf 